\title{
Boron recovery from high boron containing wastewater using modified sub-micron $\mathrm{Ca}(\mathrm{OH})_{2}$ particle
}

\author{
H. C. Tsai $\cdot$ S. L. Lo
}

Received: 27 June 2013/Revised: 16 October 2013/Accepted: 3 November 2013/Published online: 27 November 2013

(C) Islamic Azad University (IAU) 2013

\begin{abstract}
In the present study, two modified calcium hydroxide $\left(\mathrm{Ca}(\mathrm{OH})_{2}\right)$ particles, sub-micron $\mathrm{Ca}(\mathrm{OH})_{2}$ made by $\mathrm{CaCl}_{2}$ and $\mathrm{Ca}\left(\mathrm{NO}_{3}\right)_{2}$, were applied to improve efficiency of boron recovery from concentrated wastewater under mild temperature conditions. The two modified calcium hydroxide particles led to higher recovery efficiencies at $95{ }^{\circ} \mathrm{C}$ for $1 \mathrm{~h}(77.2$ and $76.3 \%)$ as compared to the efficiency by using un-modified $\mathrm{Ca}(\mathrm{OH})_{2}(67.2 \%)$. The difference was due to their different particle size constitutions. For the reaction kinetic of boron removal, it was found that the pseudo-first-order model fitted well in the experimental data. The sub-micron $\mathrm{Ca}(\mathrm{OH})_{2}$ were used to remove and recover boron from a polarizer manufacturing wastewater. The findings revealed that it is worth recovering the boron containing precipitates because of the close boron content in the precipitates (sub-micron $\mathrm{Ca}(\mathrm{OH})_{2}$ made by $\mathrm{CaCl}_{2}: 7.0 \%$, sub-micron $\mathrm{Ca}(\mathrm{OH})_{2}$ made by $\left.\mathrm{Ca}\left(\mathrm{NO}_{3}\right)_{2}: 7.1 \%\right)$ as compared to natural boron minerals (borax: $11.3 \%$ ). In addition, in order to estimate energy efficiency of boron recovery by chemical precipitation method, an evaluating formula, energy consumption of boron uptake, was developed. The value of energy consumption of boron uptake by using sub-micron $\mathrm{Ca}(\mathrm{OH})_{2}$ made by $\mathrm{CaCl}_{2}$ with the optimum condition was
\end{abstract}

Electronic supplementary material The online version of this article (doi:10.1007/s13762-013-0413-y) contains supplementary material, which is available to authorized users.

H. C. Tsai · S. L. Lo ( $\square)$

Graduate Institute of Environmental Engineering, National Taiwan University, 71 Chou-Shan Rd., Taipei 106, Taiwan e-mail: sllo@ntu.edu.tw comparatively high $\left(35.4 \mu \mathrm{g}-\mathrm{B} / \mathrm{g}-\mathrm{Ca}(\mathrm{OH})_{2} / \mathrm{kJ}\right)$. Therefore, the sub-micron $\mathrm{Ca}(\mathrm{OH})_{2}$ particles were observed more effective for boron recovery from concentrated wastewater under moderate temperatures.

Keywords Sub-micron particle $\cdot$ Chemical precipitation . Boron removal $\cdot$ Boron recovery $\cdot$ Polarizer manufacturing wastewater

\section{Introduction}

Boron compounds are widely used as raw materials in glass, detergent, and fertilizer manufacturing processes (Schubert 2003). Recently, a large amount of boric acid is used as a complex compound with iodide in polarizer manufacturing process (Robinson et al. 2005). The world consumption of boron compounds increases gradually and reached around 1.8 million tons in terms of $\mathrm{B}_{2} \mathrm{O}_{3}$ in 2005 (Roskill Information Service Ltd 2006). However, the world boron reserve is limited up to 1.176 billion ton (Önal and Burat 2008), and only few boron minerals are commercially valuable (Angulo and Crangle 2010; Girgin et al. 2010). It is needed to look for alternative boron sources to meet the increasing requirement of boron. In addition, the wastewater from polarizer manufacturing process also generated with high-level boron and might lead to a serious impact on river ecology, if disposed partially or untreated. In Taiwan, the Environmental Protection Agency sets boron discharge limit of $1 \mathrm{mg} / \mathrm{L}$, which is more stringent in comparison with the limits set by other countries and international organizations (Itakura et al. 2005; Chong et al. 2009). In order to achieve the two respect goals of new boron resource exploration and discharge limit requirement, an appropriate treatment strategy was 
proposed; high concentration boron in wastewaters can be recovered before reducing the concentration to meet the discharge criteria.

For studies of boron removal and recovery, the large majority of research studies were focused on the removal efficiencies, but few on feasibility of boron recovery, even though the result showed great potential and cost-effectiveness in boron recovery (Özdemir and Kıpçak 2010; Ezechi et al. 2011). RO technique is a primary treatment method for boron removal in desalination processes. Depended on previous studies, they all paid much attention to boron removal up to lower levels $(\sim 5 \mathrm{mg} / \mathrm{L})$ with rejection rate of about $85-95 \%$. The concentrate flux in RO system contains higher boron concentration, and it might be more potential with fewer presences of other interference for boron recovery (Redondo et al. 2003; Taniguchi et al. 2004; Oo and Ong 2010).

Boron removal by ion exchange is a developed method in recent decades (Parks and Edwards 2005; Yan et al. 2008). This method showed high potential in boron recovery (Mohapatra et al. 2008), but it could be more costly when using for wastewater treatment as compared to several waste-reuse adsorbents developed recently (Polat et al. 2004; Öztürk and Kavak 2005).

More technically and economically effective methods are warranted in order to achieve cost-effective treatment for removal and recovery of boron from concentrated wastewater. Chemical precipitation by metal hydroxide has been examined in the past few years. Boron removal by using calcium hydroxide as a mineralizer to form a $\mathrm{Ca}-\mathrm{B}$ crystal, $\mathrm{Ca}_{2} \mathrm{~B}_{2} \mathrm{O}_{5} \cdot \mathrm{H}_{2} \mathrm{O}$ (Parasibirskite), was recognized as more effective methods (Jamis et al. 2002). Irawan et al. (2011) observed significantly high boron removal efficiency at $60{ }^{\circ} \mathrm{C}$. The surface chemical reaction was assigned as the reaction limitation by estimating the activity energy of the formation of $\mathrm{Ca}_{2} \mathrm{~B}_{2} \mathrm{O}_{5} \cdot \mathrm{H}_{2} \mathrm{O}$. Itakura et al. (2005) introduced a concept of boron recovery by chemical precipitation method. In this study, phosphoric acid was added with calcium hydroxide to form a $\mathrm{Ca}-\mathrm{P}$ crystal, hydroapatite, with a much lower solubility, and to improve treatment efficiency. However, high energy requirement that is due to a longer heating time might restrict the practical application of the chemical precipitation methods. Thus, to overcome the energy-consuming process, microwave hydrothermal method was conducted and the reaction time was shortened by a rapid start-up and an increase in collision frequency for calcium and boron ions during microwave irradiation (Tsai and Lo 2011; Tsai et al. 2011). Even though microwave technologies have a high performance level in heating efficiency, their full-scale development for wastewater treatment is still a longterm goal. In 2012, an acceleration method with low initial boron concentration by using ammonia was reported (Yoshikawa et al. 2012); nevertheless, that was difficult to use in the wastewater containing high-level boron. Consequently, in this study, conventional heating method with shorter reaction time at lower temperature and modified $\mathrm{Ca}(\mathrm{OH})_{2}$ particle were considered in order to improve boron recovery efficiency on account of less energy input.

The objective of this study was to investigate the efficiencies of boron recovery from concentrated wastewater by two types of sub-micron $\mathrm{Ca}(\mathrm{OH})_{2}$ prepared via a brief way. The feasibility of boron recovery from a polarizer manufacturing wastewater was also examined. Furthermore, an evaluating equation was developed in order to give a comprehensive idea of the correlation between energy demand and boron removal efficiency.

\section{Materials and methods}

\section{Materials}

Commercial $\mathrm{Ca}(\mathrm{OH})_{2}$ without modifying $(\mathrm{CAH})$ was purchased from Merck Co. (Germany). The synthetic boron wastewater was prepared from boric acid (Nacalai tesque, Japan). The real boron wastewater was collected from the polarizer process of thin-film transistor-liquid crystal display (TFT-LCD) manufacturing facility in northern Taiwan. This wastewater contained concentrated boron $(1,046 \pm 48 \mathrm{mg} / \mathrm{L}), \quad$ iodide $(4,100 \pm 170 \mathrm{mg} / \mathrm{L})$, and potassium $(1,203 \pm 9.9 \mathrm{mg} / \mathrm{L})$ ions. The detailed characteristics are summarized in Table S1.

Synthesis of sub-micron $\mathrm{Ca}(\mathrm{OH})_{2}$ particles

In this study, two types of sub-micron $\mathrm{Ca}(\mathrm{OH})_{2}$ particles were prepared by a simplified wet chemical method, and $0.5 \mathrm{M}$ sodium hydroxide $(\mathrm{NaOH})$ (Nacalai tesque, Japan) solution was added drop by drop, at $0.5 \mathrm{~mL} / \mathrm{s}$, into the above $0.2 \mathrm{M}$ calcium chloride dihydrate $\left(\mathrm{CaCl}_{2} \cdot 2 \mathrm{H}_{2} \mathrm{O}\right)$ (Nacalai tesque, Japan) solution and $0.2 \mathrm{M}$ calcium nitrate tetrahydrate $\left(\mathrm{Ca}\left(\mathrm{NO}_{3}\right)_{2} \cdot 4 \mathrm{H}_{2} \mathrm{O} ;\right.$ J.T. Baker, USA) solution at room temperature $\left(25^{\circ} \mathrm{C}\right)$. The reactions are shown as follows:

$$
\begin{aligned}
& \mathrm{CaCl}_{2}+2 \mathrm{NaOH} \rightarrow \mathrm{Ca}(\mathrm{OH})_{2}+2 \mathrm{NaCl} \\
& \mathrm{Ca}\left(\mathrm{NO}_{3}\right)_{2}+2 \mathrm{NaOH} \rightarrow \mathrm{Ca}(\mathrm{OH})_{2}+2 \mathrm{NaNO}_{3}
\end{aligned}
$$

The mixture was stirred for $1 \mathrm{~min}$ in order to achieve uniform mixing. Then, these two precipitates were separated from liquid by a centrifuge (Z32HK, Hermle, Germany) at $8,000 \mathrm{rpm}$ for $3 \mathrm{~min}$. After that, precipitates were dried at $-58 \pm 2{ }^{\circ} \mathrm{C}$ by a freeze dryer (FD3-12P, 
KINGMECH, Taiwan), and named SM-CAC (sub-micron calcium hydroxide made by calcium chloride solution) and SM-CAN (sub-micron calcium hydroxide made by calcium nitrate solution).

Boron removal and recovery experiment

All batch experiments were conducted by chemical precipitation method and using a thermoreactor (CR 3200, WTW, Germany). The experiments were conducted at various reaction times (5-240 $\mathrm{min})$, treatment temperatures $\left(65-105^{\circ} \mathrm{C}\right)$, and dosages of $\mathrm{Ca}(\mathrm{OH})_{2}(0.05-0.2 \mathrm{~g}$ per $10 \mathrm{~mL}$ of solution). On completion of the reactions, the precipitates were separated from liquid by centrifugation at $10,000 \mathrm{rpm}$ for $5 \mathrm{~min}$ and then dried at $-58{ }^{\circ} \mathrm{C}$ in the freeze dryer. In addition, a $\mathrm{pH}$ value of 13 was chosen on the basis of previous study (Tsai and Lo 2011). Because of the ease of measurement of residual boron in solutions, the boron removal efficiency was used to estimate the efficiency of boron recovery, and it was calculated as follows:

Estimated efficiency of boron removal $\left(\mathrm{BRE}^{\prime}\right)(\%)$

$$
=\left[\frac{C_{0}-C_{\mathrm{e}}}{C_{0}}\right] \times 100
$$

where $C_{0}$ is the initial boron concentration $(\mathrm{mg} / \mathrm{L})$, and $C_{\mathrm{e}}$ is the concentration $(\mathrm{mg} / \mathrm{L})$ of the boron solution at equilibrium. In order to investigate the real boron recovery efficiency, the recovered precipitates were dissolved into distilled water by adding $0.05 \mathrm{~N} \mathrm{HCl}$ solution and the recovery efficiency was defined as follows:

Boron recovery efficiency $(\mathrm{BRE})(\%)=\left[\frac{C_{\mathrm{p}}}{C_{0}}\right] \times 100$

where $C_{\mathrm{p}}$ is the boron concentration dissolved from the precipitates. The percentage of boron content from the precipitate is expressed as follows:

Boron content $(\%)=\left[\frac{W_{\mathrm{B}}}{W_{\mathrm{p}}}\right] \times 100$

where $W_{\mathrm{B}}$ is the weight of $\mathrm{B}$ of $2(\mathrm{CaO})\left(\mathrm{B}_{2} \mathrm{O}_{3}\right)\left(\mathrm{H}_{2} \mathrm{O}\right)$ $\left(\mathrm{Ca}_{2} \mathrm{~B}_{2} \mathrm{O}_{5} \cdot \mathrm{H}_{2} \mathrm{O}\right)$ which was derived by $C_{\mathrm{p}}$. $W_{\mathrm{P}}$ is the weight of the recovered precipitates.

Analytical methods

Sizes of sub-micron $\mathrm{Ca}(\mathrm{OH})_{2}$ particles were analyzed by a particle size analyzer (Mastersizer 2000, Malvern, UK). Compositions of the precipitate were analyzed by X-ray diffraction (XRD) (X'Pert PRO, PANalytical, The Netherlands), equipped with a $\mathrm{Cu}$ target operated at $45 \mathrm{kV}$ and $40 \mathrm{~mA}$. The surface structures of the precipitate were observed by scanning electron microscopy (SEM) (JSM$6500 \mathrm{~F}$, JEOL, Japan). The functional groups of the precipitate and sub-micron $\mathrm{Ca}(\mathrm{OH})_{2}$ particles were identified by attenuated total reflectance Fourier transform infrared spectroscopy (ATR-FTIR) (Spectrum 100, PerkinElmer, USA). Boron concentrations in solutions were measured by Azomethine-H method (López et al. 1993) with a UVvisible spectrophotometer (Cintra 20, GBC, Australia) at $410 \mathrm{~nm}$.

\section{Results and discussion}

Characterization of sub-micron $\mathrm{Ca}(\mathrm{OH})_{2}$ particles

The diffraction peaks of XRD analysis results show that $\mathrm{Ca}(\mathrm{OH})_{2}$ is the primary crystal phase of SM-CAC and SM-CAN [Online Resource 1_Fig. S1(a)]. For FTIR analysis, the slight carbonation of three $\mathrm{Ca}(\mathrm{OH})_{2}$ particles was identified by the adsorption peaks of the out-of-plane bending of $\mathrm{CO}_{3}{ }^{2-}$ of $\mathrm{CaCO}_{3}$ at 1,466 and $873 \mathrm{~cm}^{-1}$ [Online Resource 1_Fig. S1(b); Böke et al. 2004]. The SEM photographs of the three $\mathrm{Ca}(\mathrm{OH})_{2}$ particles were shown in Online Resource 1_Fig. S2. For the particle size distributions of SM-CAC and SM-CAN (Online Resource 1_Table S2), their distributions ranged from around 1 to $10 \mu \mathrm{m}$ and peaked at 2.2 and $2.5 \mu \mathrm{m}$. Additionally, the average particle sizes of SM-CAC and SM-CAN were 2.8 and $2.9 \mu \mathrm{m}$, respectively. For $\mathrm{CAH}$, the particle size distribution shows a fluctuant curve. It is interesting to note that the particle size and surface area analysis results of these three $\mathrm{Ca}(\mathrm{OH})_{2}$ particles show an inverse correlation. The average particle size of CAH $(11.3 \mu \mathrm{m})$ was almost four times larger than those of SM-CAC and SMCAN; however, CAH particles have higher surface area (Online Resource 1_Table S2). It was due to the smallsize particles in $\mathrm{CAH}$, which contribute to the large majority of the surface area.

Boron recovery efficiencies by sub-micron CAC and CAN

To evaluate the effects of the sub-micron $\mathrm{Ca}(\mathrm{OH})_{2}$ particles on boron recovery, $10 \mathrm{~g} / \mathrm{L}$ of each CAH, SM-CAC, and SM-CAN was added into $1,000 \mathrm{mg} / \mathrm{L}$ of boron solutions at 95 and $130{ }^{\circ} \mathrm{C}$ for $1 \mathrm{~h}$. In addition, these two reaction temperatures were represented as the reaction below and above the boiling point of water to give a preliminary idea of the temperature effect. As shown in Fig. 1, the estimated boron removal efficiencies (BRE') by the three $\mathrm{Ca}(\mathrm{OH})_{2}$ particle additions at $130{ }^{\circ} \mathrm{C}$ reached up to $93-95 \%$. It was also noted that the efficiencies peaked at $130{ }^{\circ} \mathrm{C}$ during the experiments at various 
Fig. 1 Effect of $\mathrm{CAH}$ (commercial $\mathrm{Ca}(\mathrm{OH})_{2}$ without modifying) and SM-CAC and SM-CAN (sub-micron $\mathrm{Ca}(\mathrm{OH})_{2}$ made by $\mathrm{CaCl}_{2}$ and $\left.\mathrm{Ca}\left(\mathrm{NO}_{3}\right)_{2}\right)$ particles on boron removal at 95 and $130{ }^{\circ} \mathrm{C}$ (initial boron concentration $=1,000 \mathrm{mg} / \mathrm{L}$, dosage $=10 \mathrm{~g} / \mathrm{L}, t=1 \mathrm{~h}$ )

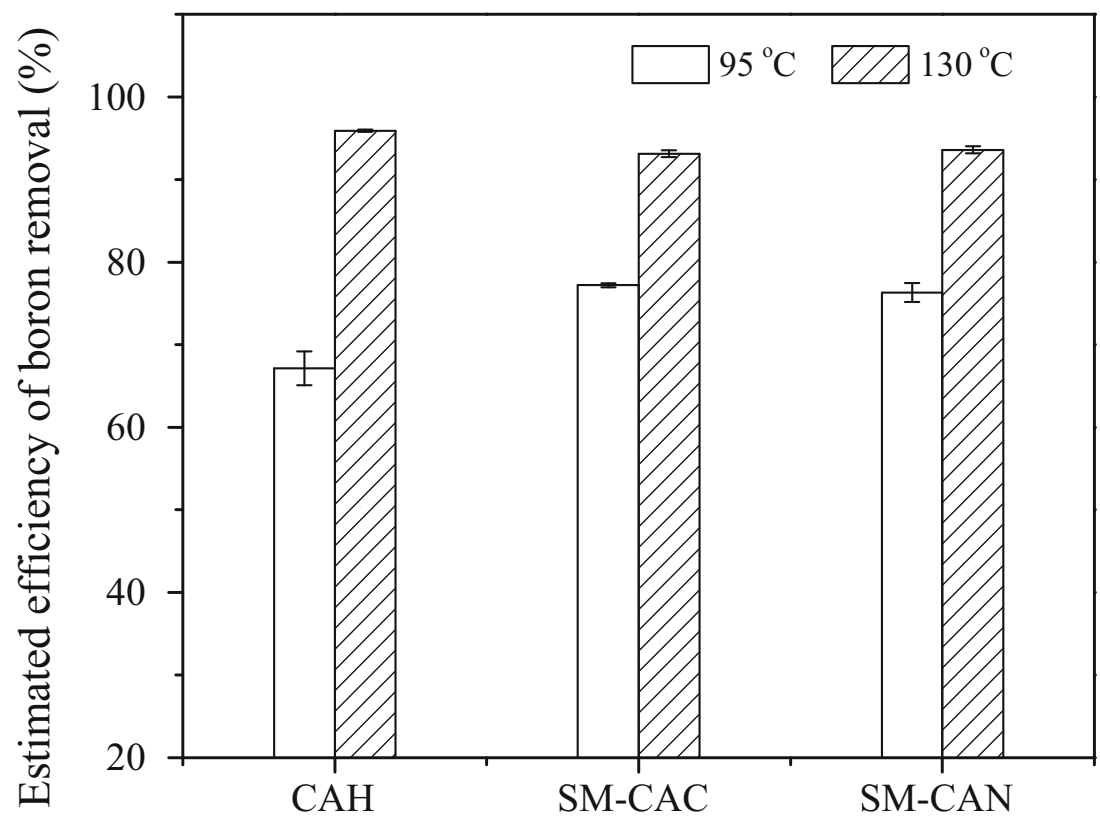

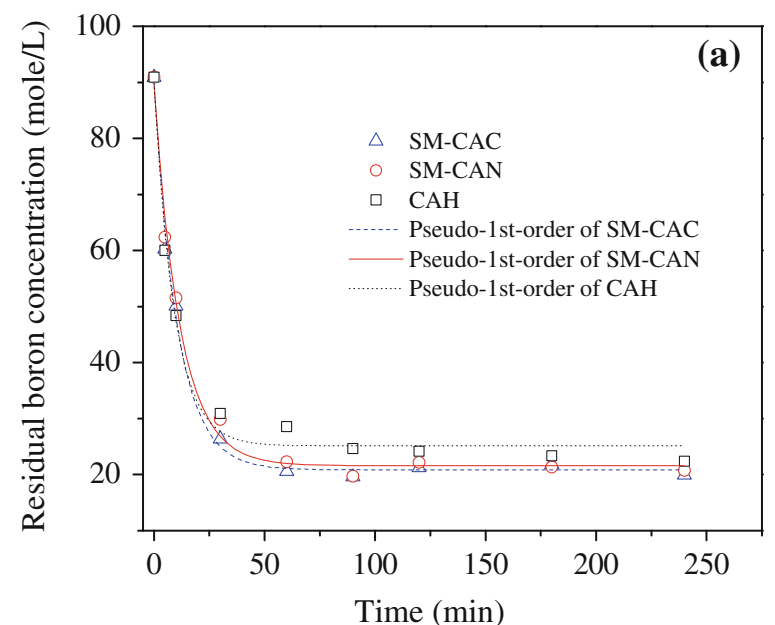

Fig. 2 Residual boron concentration at different reaction times and the experimental data fitted by a the pseudo-first-order model and b the second-order model (initial boron concentration $=1,000 \mathrm{mg} / \mathrm{L}$,

reaction temperatures $\left(55-170{ }^{\circ} \mathrm{C}\right.$; Itakura et al. 2005). The differences of BRE' were observed apparently between the three additions at $95{ }^{\circ} \mathrm{C}$. The result showed that BRE' using CAH was $10 \%$ lower than those achieved with SM-CAC and SM-CAN (77.2 and $76.3 \%$ ). The result showed that characteristics of modified $\mathrm{Ca}(\mathrm{OH})_{2}$ particles may be helpful in enhancing reaction rate of boron recovery at lower energy input, and SM$\mathrm{CAC}$ and SM-CAN were chosen as the mineralizer for proposed boron recovery method in the subsequent experiments.

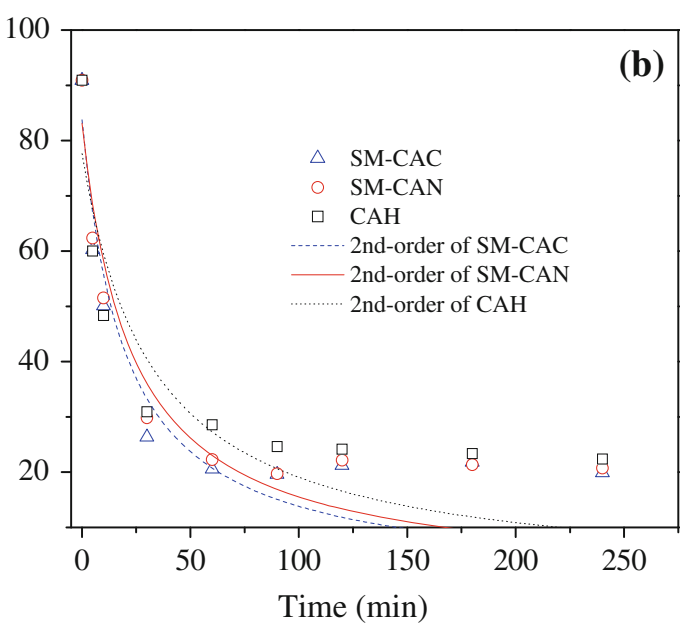

dosage $=10 \mathrm{~g} / \mathrm{L}$, and $T=95^{\circ} \mathrm{C}, \mathrm{CAH}$ : commercial $\mathrm{Ca}(\mathrm{OH})_{2}$ without modifying, $S M-C A C$ sub-micron $\mathrm{Ca}(\mathrm{OH})_{2}$ made by $\mathrm{CaCl}_{2}, S M$ CAN sub-micron $\mathrm{Ca}(\mathrm{OH})_{2}$ made by $\left.\mathrm{Ca}\left(\mathrm{NO}_{3}\right)_{2}\right)$

\section{Reaction time}

Effects of reaction times on boron recovery were investigated by adding $10 \mathrm{~g} / \mathrm{L}$ of SM-CAC and SM-CAN in $1,000 \mathrm{mg} / \mathrm{L}(91 \mathrm{~mol} / \mathrm{L})$ of boron solutions at $95{ }^{\circ} \mathrm{C}$ from 5 min to 4 h (Fig. 2). For the SM-CAC addition, residual boron concentrations dramatically decreased to around $26 \mathrm{~mol} / \mathrm{L}$ within $30 \mathrm{~min}$. In the case of SM-CAN addition, the residual boron concentration reduced to about $30 \mathrm{~mol} / \mathrm{L}$ after $30 \mathrm{~min}$. After a long reaction time (e.g., $1 \mathrm{~h}$ ), the overall boron recovery efficiencies for both sub- 
micron $\mathrm{Ca}(\mathrm{OH})_{2}$ particles were comparable. Thus, 60 min of reaction time may be more adequate, and it was chosen as the optimum reaction time in the subsequent experiments.

Moreover, in order to fully comprehend the reaction kinetic of boron recovery and to compare their rate constants $k$, two kinetic models, pseudo-first-order and second-order model, were employed (Fig. 2). The quite high correlation coefficients were observed when the pseudofirst-order model was applied (Table 1). This model expression also provides the well correlation of experimental data in the previous study (Irawan et al. 2011). In contrast, the correlation coefficients were comparatively lower when fitting the data by the second-order model. It may be due to the fairly low solubility of $\mathrm{Ca}(\mathrm{OH})_{2}$ $\left(\mathrm{Ksp}=5.5 \times 10^{-6}\right.$ at $25^{\circ} \mathrm{C}$; Schaezler 1978). This low solubility property can nearly keep the concentrations of calcium ions in solutions as a constant until the concentration of $\mathrm{Ca}(\mathrm{OH})_{2}$ particle was less than its solubility. Therefore, it seems that the concentrations of calcium

Table 1 Parameters of reaction kinetic on boron removal by two kinetic models

\begin{tabular}{llllll}
\hline & \multicolumn{2}{l}{ Pseudo-first-order model } & & \multicolumn{2}{l}{ Second-order model } \\
\cline { 2 - 3 } & $R^{2}$ & $k\left(\mathrm{~min}^{-1}\right)$ & & $R^{2}$ & $k(1 /$ mole min $)$ \\
\hline CAH & 0.99 & 0.108 & & 0.85 & 0.0004 \\
SM-CAC & 0.99 & 0.094 & & 0.87 & 0.0006 \\
SM-CAN & 0.99 & 0.085 & & 0.78 & 0.0005 \\
\hline
\end{tabular}

ions stayed almost the same during the formation of $\mathrm{Ca}_{2} \mathrm{~B}_{2} \mathrm{O}_{5} \cdot \mathrm{H}_{2} \mathrm{O}$. Even though there was no significant difference between the concentrations of $\mathrm{Ca}(\mathrm{OH})_{2}$ and boron in solutions (molar ratio of $\mathrm{Ca}(\mathrm{OH})_{2}$ and $\left.\mathrm{B}(\mathrm{OH})_{3}=1.48: 1\right)$, this phenomenon might result in the well correlation of reaction kinetic of boron recovery by the pseudo-first-order model.

\section{Reaction temperature}

Effects of reaction temperatures on boron recovery by SM-CAC and SM-CAN with reaction time of $1 \mathrm{~h}$ are shown in Fig. 3. The residual boron concentrations by adding the two $\mathrm{Ca}(\mathrm{OH})_{2}$ particles decreased sharply as temperature increased from 65 to $95^{\circ} \mathrm{C}$. From 95 to $105^{\circ} \mathrm{C}$, the residual boron concentrations stayed essentially the same (e.g., SM-CAC: 228-232 mg/L). There was no significant difference in the decreasing trends of residual boron concentration of SM-CAC and SM-CAN. According to the previous study, the boron concentrations decreased apparently when the temperatures were above $115^{\circ} \mathrm{C}$ (Tsai and Lo 2011). SEM analyses were made on the precipitates obtained by the two types of sub-micron $\mathrm{Ca}(\mathrm{OH})_{2}$ additions at 95 and $105{ }^{\circ} \mathrm{C}$ (Online Resource 1_Fig. S2). At $95^{\circ} \mathrm{C}$ of reaction time, plate-like crystals were observed in the case of SM-CAC and SM-CAN additions. With increasing the temperatures (from 95 to $105^{\circ} \mathrm{C}$ ), the plate-like crystals became finer and turned into needle-like crystals in the two types of sub-micron $\mathrm{Ca}(\mathrm{OH})_{2}$ additions.
Fig. 3 Effects of reaction temperatures on residual boron concentrations (initial boron concentration $=1,000 \mathrm{mg} / \mathrm{L}$, dosage $=10 \mathrm{~g} / \mathrm{L}, t=1 \mathrm{~h}, S M$ $C A C$ sub-micron $\mathrm{Ca}(\mathrm{OH})_{2}$ made by $\mathrm{CaCl}_{2}, S M-C A N$ sub-micron $\mathrm{Ca}(\mathrm{OH})_{2}$ made by $\left.\mathrm{Ca}\left(\mathrm{NO}_{3}\right)_{2}\right)$

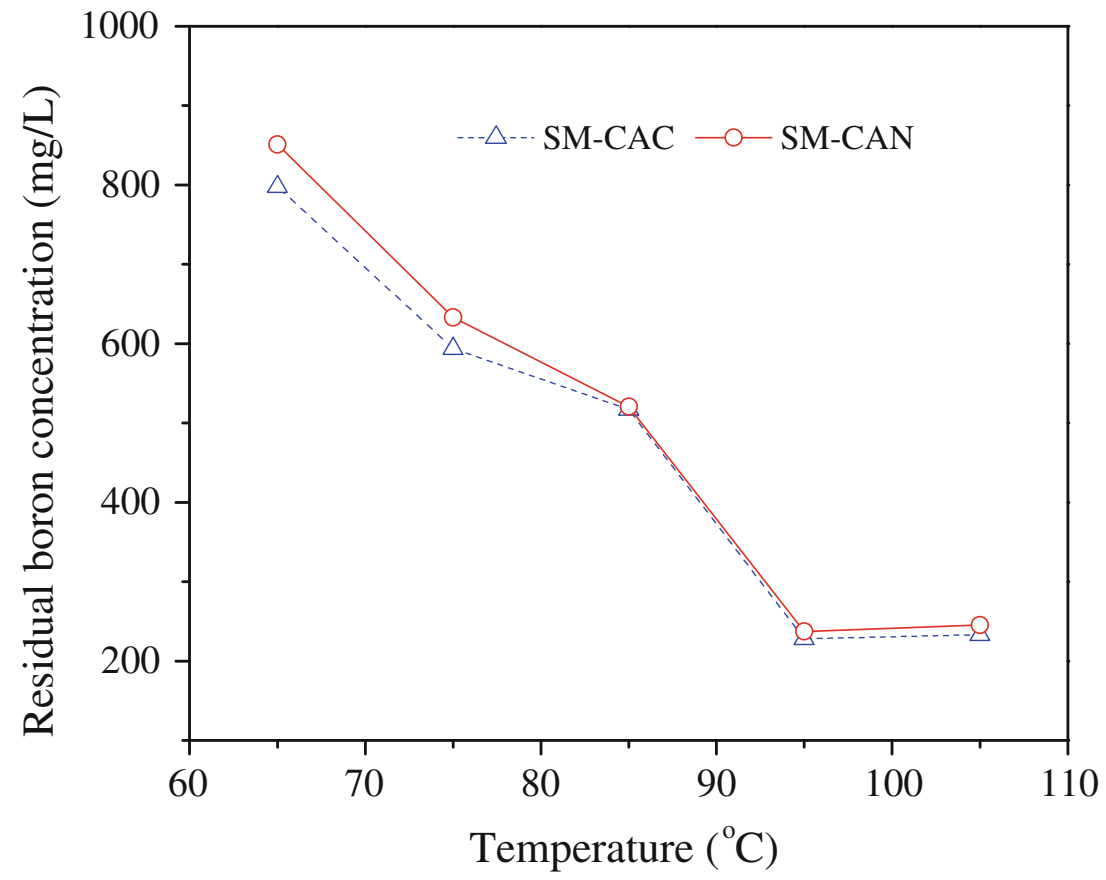


Fig. 4 Effects of SM-CAC and SM-CAN (sub-micron $\mathrm{Ca}(\mathrm{OH})_{2}$ made by $\mathrm{CaCl}_{2}$ and $\mathrm{Ca}\left(\mathrm{NO}_{3}\right)_{2}$ ) doses on boron uptake (initial boron

concentration $=1,000 \mathrm{mg} / \mathrm{L}$, $T=95{ }^{\circ} \mathrm{C}, t=1 \mathrm{~h}, S M-C A C$ sub-micron $\mathrm{Ca}(\mathrm{OH})_{2}$ made by $\mathrm{CaCl}_{2}, S M-C A N$ sub-micron $\mathrm{Ca}(\mathrm{OH})_{2}$ made by $\left.\mathrm{Ca}\left(\mathrm{NO}_{3}\right)_{2}\right)$

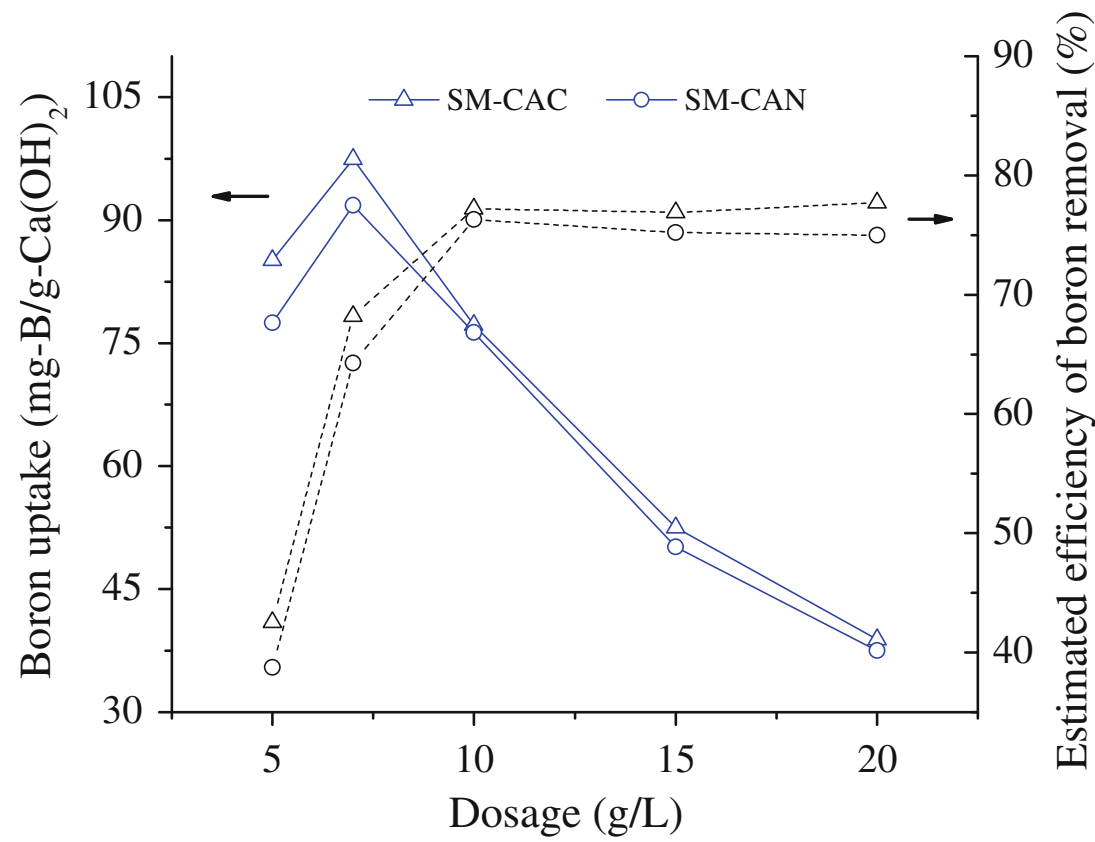

Dosages of sub-micron CAC and CAN

To evaluate the effects of doses on boron uptake, five doses of the two types of sub-micron $\mathrm{Ca}(\mathrm{OH})_{2}$ particles were added into $1,000 \mathrm{mg} / \mathrm{L}$ of boron solutions at $95{ }^{\circ} \mathrm{C}$ for $1 \mathrm{~h}$. Figure 4 shows percentage recoveries of boron and masses of boron-recovered unit mass of sub-micron $\mathrm{Ca}(\mathrm{OH})_{2}$ with different doses of sub-micron $\mathrm{Ca}(\mathrm{OH})_{2}$. A similar trend was observed for SM-CAC and SM-CAN as the mass of boron recovery per unit mass of sub-micron $\mathrm{Ca}(\mathrm{OH})_{2}$ increased to 97 and $92 \mathrm{mg}-\mathrm{B} / \mathrm{g}-\mathrm{Ca}(\mathrm{OH})_{2}$ with increasing doses from 5 to $7 \mathrm{~g} / \mathrm{L}$. However, it dropped sharply on increasing the dose above $7 \mathrm{~g} / \mathrm{L}$. Moreover, 77 and $76 \%$ BRE' were observed for SM-CAC and SM-CAN, respectively, and became essentially the same until $20 \mathrm{~g} / \mathrm{L}$ of dose.

\section{Mechanisms}

Physical characteristics of modified $\mathrm{Ca}(\mathrm{OH})_{2}$ particle may be a key role for an improvement of boron recovery, and the correlation of the physical properties with recovery efficiencies was proposed by the following two aspects of illustration. The first is adsorption of boron from $\mathrm{Ca}(\mathrm{OH})_{2}$ particles. Boric acid is a weak acid with pKa of 9.2 (at $25^{\circ} \mathrm{C}$ ). In aqueous systems, boric acid and borate ions are common forms, and their fractions of concentration are depended on different $\mathrm{pH}$ values in the solutions. In addition, polynuclear boron species are present at concentrations more than $25 \mathrm{mmol} / \mathrm{L}$ when $\mathrm{pH}$ values are from 6 to 11 (World Health Organization 1998). That include $\quad \mathrm{B}_{3} \mathrm{~B}_{3}(\mathrm{OH})_{4}^{-}, \quad \mathrm{B}_{3} \mathrm{~B}_{3}(\mathrm{OH})_{5}^{2-}, \quad \mathrm{B}_{5} \mathrm{~B}_{6}(\mathrm{OH})_{4}^{-}$, and $\mathrm{B}_{4} \mathrm{~B}_{5}(\mathrm{OH})_{4}^{2-}$ (Kabay et al. 2010). In the polarizer wastewater, boron concentration is about $1,000 \mathrm{mg} / \mathrm{L}$ (91 mmol/L); therefore, several polynuclear boron species may exist under the specific range of $\mathrm{pH}$. Because the $\mathrm{pH}$ value in this study was more than 11 , the concentrations of polynuclear boron species might be much less than that of borate ions in the solutions (Anderson et al. 1963; Hirao et al. 1979).

In the beginning of the reaction, the presences of calcium and borate ions in solutions would lead to formation of $\mathrm{Ca}-\mathrm{B}$ ionic pairs, $\left[\mathrm{CaB}(\mathrm{OH})_{4}\right]^{+}$, under base condition. Consequently, besides borate ion $\left(\mathrm{B}(\mathrm{OH})_{4}^{-}\right),\left[\mathrm{CaB}(\mathrm{OH})_{4}\right]^{+}$ was the minor dominate soluble boron species in the solutions (Mattigod et al. 1985). The equation is shown as follows:

$\mathrm{Ca}^{2+}+\mathrm{B}(\mathrm{OH})_{4}^{-} \Leftrightarrow\left[\mathrm{CaB}(\mathrm{OH})_{4}\right]^{+}, \quad \mathrm{pKa}=1.80$

In addition, the point of zero charge of $\mathrm{Ca}(\mathrm{OH})_{2}$ was around 12.9 (Parks 1967), and it was higher than the final $\mathrm{pH}$ of the solutions in this study (12.2-12.7). This meant that the surface of $\mathrm{Ca}(\mathrm{OH})_{2}$ particle may have less positive charge and that could facilitate the adsorption of negatively charged ions (e.g., $\mathrm{B}(\mathrm{OH})_{4}^{-}$and $\mathrm{OH}^{-}$). Furthermore, more hydroxide ions may compete with borate ions for the adsorption sites of $\mathrm{Ca}(\mathrm{OH})_{2}$ particles in the base condition (Mattigod et al. 1985).

In order to further confirm the adsorbed functional groups on the surface of three $\mathrm{Ca}(\mathrm{OH})_{2}$ particles, $\mathrm{CAH}$, SM-CAC, and SM-CAN were added into the solutions containing $1,000 \mathrm{mg} / \mathrm{L}$ of boron, and then, their 
Fig. 5 a The rates of boron removal versus reaction times and $\mathbf{b}$ the scheme for the variation in the extent of reaction of $\mathrm{Ca}(\mathrm{OH})_{2}$ particles (CAH: commercial $\mathrm{Ca}(\mathrm{OH})_{2}$ without modifying, $S M-C A C$ sub-micron $\mathrm{Ca}(\mathrm{OH})_{2}$ made by $\mathrm{CaCl}_{2}, S M-C A N$ sub-micron $\mathrm{Ca}(\mathrm{OH})_{2}$ made by $\left.\mathrm{Ca}\left(\mathrm{NO}_{3}\right)_{2}\right)$

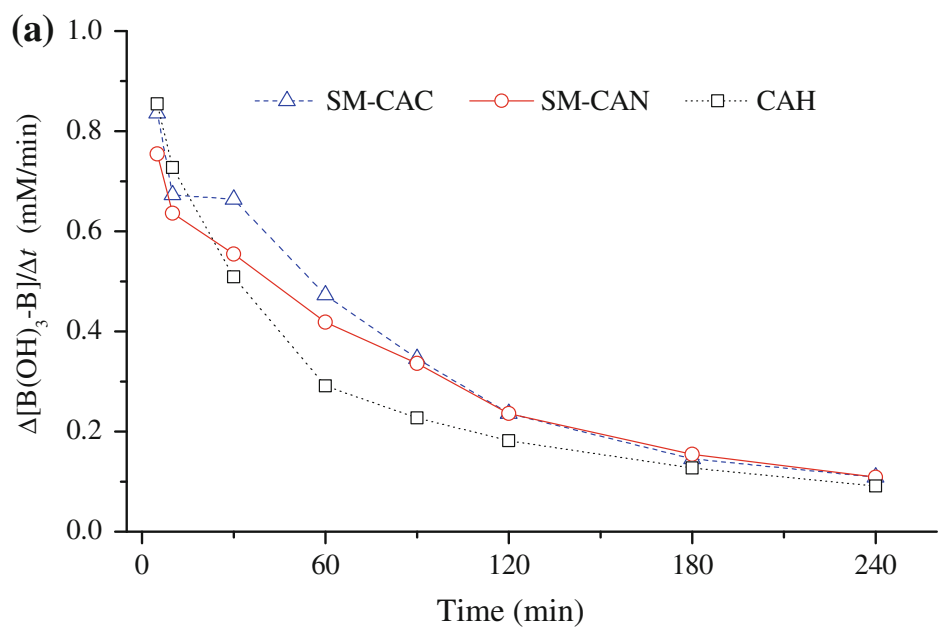

(b)

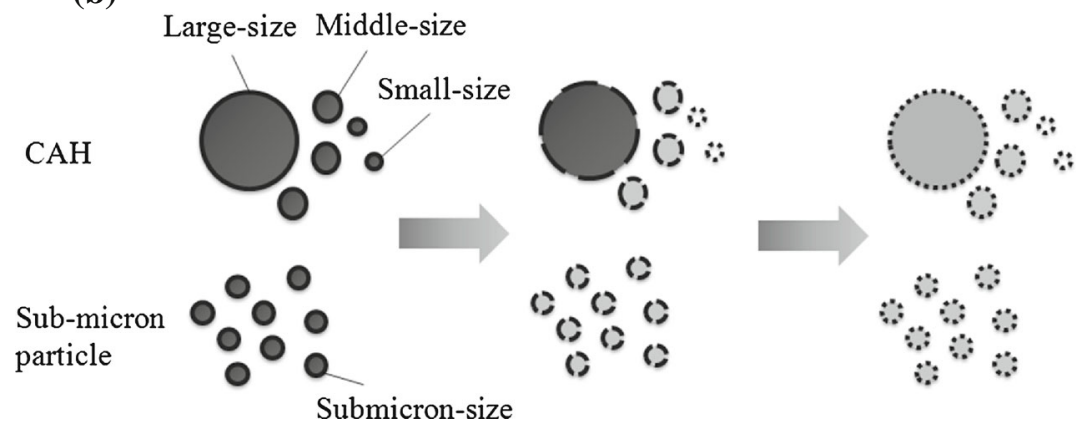

precipitates were collected after $1 \mathrm{~h}$ of reaction time at room temperature. The result of FTIR analysis is shown in Online Resource 1_Fig. S4. Based on previous studies (Jun et al. 1995; Su and Suarez 1995), the bands at $1,350 \mathrm{~cm}^{-1}$ (SM-CAC and SM-CAN) and $1,420 \mathrm{~cm}^{-1}$ $(\mathrm{CAH})$ correspond to asymmetric stretching of $\mathrm{B}-\mathrm{O}$ in $\mathrm{B}(\mathrm{OH})_{3}$. The appearance of neutral trigonal boron may be due to absence of its competitor, whereas borate ions compete with hydroxide ions at high pHs. Therefore, trigonal boron provided relatively mild affinity for the positively charged surface of $\mathrm{Ca}(\mathrm{OH})_{2}$ particle. The adsorption peaks at $927 \mathrm{~cm}^{-1}$ (SM-CAC and SM-CAN) and $908 \mathrm{~cm}^{-1}(\mathrm{CAH})$ were assigned to overlap peak between asymmetric stretching of $\mathrm{B}-\mathrm{O}$ of tetrahedral boron and symmetric stretching of $\mathrm{B}-\mathrm{O}$ in trigonal boron. Moreover, the absorbance of the precipitate formed from $\mathrm{CAH}$ was stronger than those formed from the two type of sub-micron $\mathrm{Ca}(\mathrm{OH})_{2}$. The result indicates that both trigonal and tetrahedral boron occupied the adsorption sites of the three $\mathrm{Ca}(\mathrm{OH})_{2}$ particles. The stronger appearance at $908 \mathrm{~cm}^{-1}$ from the CAH addition implies a higher ability of boron adsorption and that might also improve the boron removal rate by increasing the collision frequency between $\mathrm{Ca}(\mathrm{OH})_{2}$ and boron in the beginning of the reaction.
Furthermore, the rate of $\mathrm{Ca}_{2} \mathrm{~B}_{2} \mathrm{O}_{5} \cdot \mathrm{H}_{2} \mathrm{O}$ formation may also play a main role in the various boron recovery efficiencies of three $\mathrm{Ca}(\mathrm{OH})_{2}$ additions. Generally, the crystal growth rate correlated strongly with two driving forces, mass transport (diffusion) and surface reaction, and they are exponentially dependent on temperature (Mullin 2001). However, the rate of mass transport varies inversely with particle diameter, whereas the rate of surface reaction is independent of particle diameter (Fogler 2004). Under higher reaction temperature $\left(130^{\circ} \mathrm{C}\right)$, two driving forces may show quite rapid rates, and thus, the efficiencies by using the three $\mathrm{Ca}(\mathrm{OH})_{2}$ particles reached at higher levels (see Fig. 1). However, the rates of mass transport and surface reaction would reduce under low reaction temperatures, in which different particle size constitutions may affect the rate of crystal growth and boron recovery. The lower average particle size in SM$\mathrm{CAC}$ and SM-CAN may provide higher mass transport rates of soluble boron $\left(\mathrm{B}(\mathrm{OH})_{3}\right.$ and $\left.\mathrm{B}(\mathrm{OH})_{4}^{-}\right)$in solutions and that would lead to the higher rates of $\mathrm{Ca}_{2} \mathrm{~B}_{2} \mathrm{O}_{5} \cdot \mathrm{H}_{2} \mathrm{O}$ formation.

In order to observe the detailed variation in reaction rate of boron recovery between the three $\mathrm{Ca}(\mathrm{OH})_{2}$ additions, boron recovery rates $\left(\Delta\left[\mathrm{B}(\mathrm{OH})_{3}-\mathrm{B}\right] / \Delta t\right)$ were estimated by the experimental data (Fig. 5a). In addition, the 
Table 2 Energy efficiency of boron uptake by chemical precipitation with various conditions

\begin{tabular}{lllllrrr}
\hline Type of $\mathrm{Ca}(\mathrm{OH})_{2}$ & $T_{\mathrm{s}}\left({ }^{\circ} \mathrm{C}\right)$ & $t(\mathrm{~h})$ & $\begin{array}{l}\mathrm{B}-\text {-uptake } \\
(\mathrm{mg}-\mathrm{B} / \mathrm{g}-\mathrm{Ca})\end{array}$ & $\begin{array}{l}\text { Residual B } \\
(\mathrm{mg} / \mathrm{L})\end{array}$ & $\mathrm{Q}(\mathrm{kJ})$ & $\begin{array}{l}\text { ECBU } \\
\left(\mu \mathrm{g}-\mathrm{B} / \mathrm{g}-\mathrm{Ca}(\mathrm{OH})_{2} / \mathrm{kJ}\right)\end{array}$ & Reference \\
\hline SM-CAC & 95 & 1 & 77.4 & $226(77.4 \%)^{\mathrm{a}}$ & 2,189 & 35.4 & This work \\
$\mathrm{CAH}$ & 95 & 1 & 67.2 & $380(67.2 \%)$ & 2,189 & 31.3 & This work \\
Commercial $\mathrm{Ca}(\mathrm{OH})_{2}$ & 90 & 2 & 14.0 & $53(92.9 \%)$ & 3,812 & 3.7 & Tsai and Lo (2011) \\
Commercial $\mathrm{Ca}(\mathrm{OH})_{2}$ & 80 & 4 & 65.3 & $98(87.0 \%)$ & 6,305 & 10.4 & López et al. (1993) \\
Commercial $\mathrm{Ca}(\mathrm{OH})_{2}$ & 60 & 8 & 65.3 & $98(87.0 \%)$ & 8,295 & 7.9 & \\
\hline
\end{tabular}

a Boron recovery efficiency (BRE')

scheme for the variation in the extent of reaction of $\mathrm{Ca}(\mathrm{OH})_{2}$ particles between the three $\mathrm{Ca}(\mathrm{OH})_{2}$ additions was also proposed in Fig. 5b. In the beginning of the reaction $(5-10 \mathrm{~min})$, the boron recovery rates by using $\mathrm{CAH}$ particles showed higher levels. After $10 \mathrm{~min}$ of reaction time, the rates in $\mathrm{CAH}$ addition had a sharp decrease, whereas the rates in SM-CAC and SM-CAN additions declined gradually. The variation in boron recovery rates might be attributed to the various number concentrations of particles of CAH, SM-CAC, and SMCAN in solutions. When the number concentration of particles is higher, their diffusion layers may overlap with each other. Consequently, the crystal growth rate would be accelerated by the steeper concentration gradient of solute in diffusion layer (Sugimoto 2011). In case of CAH addition, the rate of $\mathrm{Ca}_{2} \mathrm{~B}_{2} \mathrm{O}_{5} \cdot \mathrm{H}_{2} \mathrm{O}$ formation may be enhanced by the higher number concentration of $\mathrm{Ca}(\mathrm{OH})_{2}$ particles contributed by the small-size particles. The boron recovery rates by using $\mathrm{CAH}$ were quite high in the beginning of the reaction (middle step of Fig. 5b). With increasing reaction time, the small-size particles may be consumed completely, and middle-size and large-size particles became the major and minor reactive particles (the third step of Fig. 5b). As a result, the rates of $\mathrm{Ca}_{2} \mathrm{~B}_{2} \mathrm{O}_{5} \cdot \mathrm{H}_{2} \mathrm{O}$ formation in case of the sub-micron $\mathrm{Ca}(\mathrm{OH})_{2}$ additions would be higher than those in case of $\mathrm{CAH}$ addition.

\section{Comparison of energy consumption}

The boron recovery by chemical precipitation method usually requires high energy consumption for heating. Reaction temperature and time are highly relative with the amount of energy demand. It is more appropriate to take into account the correlation between the two parameters and energy consumption to estimate the energy efficiency of this treatment method. In this study, an equation was derived to evaluate the energy consumption of boron uptake (ECBU) $(\mathrm{mg}-\mathrm{B} / \mathrm{g}-\mathrm{Ca} / \mathrm{kJ})$. This equation included the value of boron uptake (B-uptake) and energy consumption (Q) by using the formula of specific heat capacity
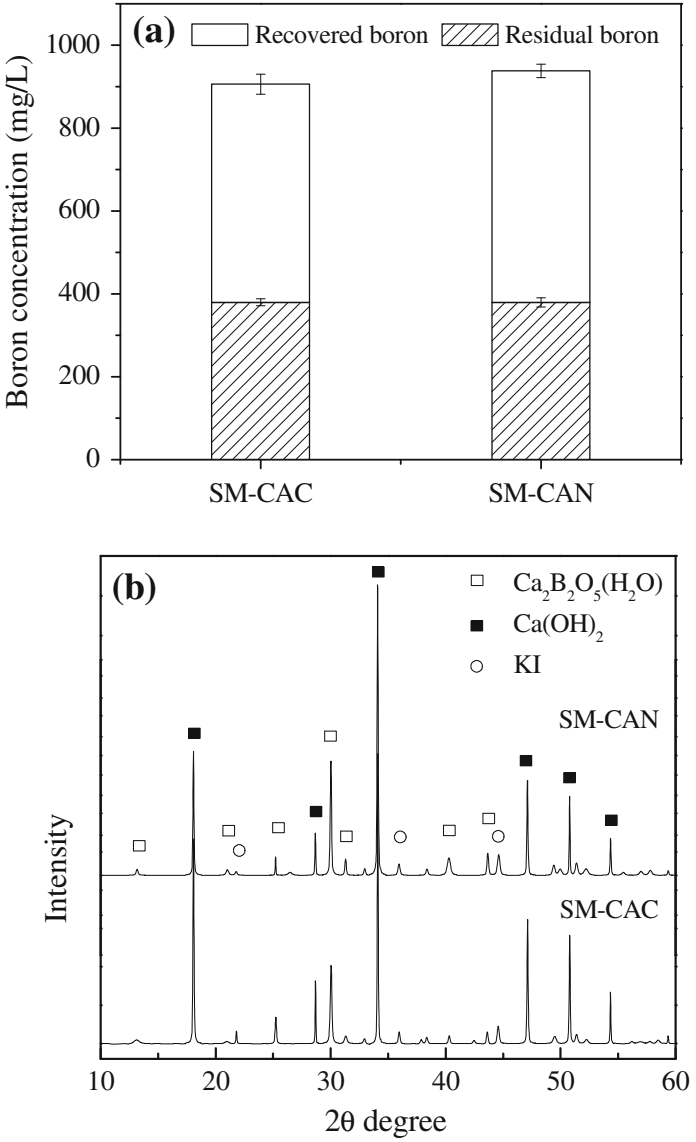

Fig. 6 a Boron removal and recovery concentrations from polarizer manufacturing wastewater and $\mathbf{b}$ X-ray diffraction patterns of precipitates made from the two types of sub-micron $\mathrm{Ca}(\mathrm{OH})_{2}$ additions (Dosage $=10 \mathrm{~g} / \mathrm{L}, T=95^{\circ} \mathrm{C}, t=1 \mathrm{~h}, S M-C A C$ submicron $\mathrm{Ca}(\mathrm{OH})_{2}$ made by $\mathrm{CaCl}_{2}, S M-C A N$ sub-micron $\mathrm{Ca}(\mathrm{OH})_{2}$ made by $\left.\mathrm{Ca}\left(\mathrm{NO}_{3}\right)_{2}\right)$

to estimate the energy transferred from the thermoreactor. It is described as follows:

$\mathrm{ECBU}=\mathrm{B}$-uptake $/ Q$

where $\mathrm{B}$-uptake is the masses of boron removed unit mass of $\mathrm{Ca}(\mathrm{OH})_{2}(\mathrm{mg}-\mathrm{B} / \mathrm{g}-\mathrm{Ca}) . Q$ is the energy transferred $(\mathrm{kJ})$. After deriving Eq. 7 in an appropriate way (from Eq. S1 to 
Table 3 Residual and recovered concentrations of other ions by polarizer manufacturing wastewater treatment

\begin{tabular}{lllrrr}
\hline & \multicolumn{2}{l}{ Residual concentration $(\mathrm{mg} / \mathrm{L})$} & & \multicolumn{2}{c}{ Recovered concentration $(\mathrm{mg} / \mathrm{L})$} \\
\cline { 2 - 3 } \cline { 5 - 6 } & SM-CAC & SM-CAN & & SM-CAC & SM-CAN \\
\hline $\mathrm{I}^{-}$ & $3,986.3 \pm 109.7$ & $4,042.1 \pm 52.2$ & $81.8 \pm 0.1$ & $35.6 \pm 20.0$ \\
$\mathrm{~K}^{+}$ & $1,184.0 \pm 35.4$ & $1,221.0 \pm 43.8$ & $35.1 \pm 1.0$ & $38.1 \pm 5.0$ \\
$\mathrm{Ca}^{2+}$ & $1,740.5 \pm 161.9$ & $1,964.0 \pm 134.4$ & & $3,491.5 \pm 738.9$ & $3,408.5 \pm 444.8$ \\
$\mathrm{Na}^{+}$ & $49.5 \pm 19.1$ & $108.5 \pm 2.1$ & $52.6 \pm 11.0$ & $57.7 \pm 2.7$ \\
\hline
\end{tabular}

Table 4 Comparison of boron treatment methods

\begin{tabular}{|c|c|c|c|c|}
\hline Technology & $\begin{array}{l}\mathrm{RE}(\%) / \mathrm{RC} \\
(\mathrm{mg} / \mathrm{L})^{\mathrm{a}}\end{array}$ & Product for B recovery & Comment & Reference \\
\hline $\begin{array}{l}\text { Chemical } \\
\text { precipitation }\end{array}$ & $90-99 / 0.5$ & $\begin{array}{l}\text { B containing compound } \\
\text { (solid) }\end{array}$ & $\begin{array}{l}\text { Long reaction time (conventional } \\
\text { heating) } \\
\text { High dose } \\
\text { Large amount of sludge } \\
\text { High influent conc. } \\
\quad(400-1,000 \mathrm{mg} / \mathrm{L})\end{array}$ & $\begin{array}{l}\text { Jamis et al. (2002), Itakura et al. (2005), } \\
\text { Tsai and Lo (2011) }\end{array}$ \\
\hline $\begin{array}{l}\text { Reverse } \\
\text { osmosis }\end{array}$ & $85-95 / 0.4$ & $\begin{array}{l}\text { B containing concentrated } \\
\text { solution (liquid) }\end{array}$ & $\begin{array}{l}\text { Expensive } \\
\text { Required pretreatment } \\
\text { Usually for desalination (B in } \\
\text { seawater is about } 5 \mathrm{mg} / \mathrm{L} \text { ) } \\
\mathrm{pH} \text { and operating pressure }\end{array}$ & $\begin{array}{l}\text { Redondo et al. (2003), Taniguchi et al. } \\
\text { (2004), Oo and Ong (2010) }\end{array}$ \\
\hline \multicolumn{5}{|l|}{ Adsorption } \\
\hline Ion exchange & $95-99 / 0.05$ & $\begin{array}{l}\text { Elution of B from resins } \\
\text { (liquid) }\end{array}$ & $\begin{array}{l}\text { Expensive } \\
\text { Low residual conc. } \\
\text { Boron selectivity } \\
\text { Low influent conc. (1-100 mg/L) }\end{array}$ & $\begin{array}{l}\text { Parks and Edwards (2005), Simonnot et al. } \\
\text { (2000), Kabay et al. (2007) }\end{array}$ \\
\hline Adsorbent & $50-90 / 0.5$ & $\begin{array}{l}\text { B adsorbed precipitate } \\
\text { (solid) }\end{array}$ & $\begin{array}{l}\text { Long reaction time } \\
\text { High dose } \\
\text { Large amount of sludge } \\
\text { Best removal from pH } 6-9 \\
\text { Low influent conc. }(5-100 \mathrm{mg} / \mathrm{L})\end{array}$ & $\begin{array}{l}\text { Parks and Edwards (2005), del Mar de la } \\
\text { Fuente García-Soto and Camacho } \\
\text { (2006), Dionisiou et al. (2006) }\end{array}$ \\
\hline
\end{tabular}

${ }^{a}$ Removal efficiency (\%)/residual concentration (mg/L)

Eq. S10 in the supplementary data), the ECBU equation can be expressed as follows:

$$
\begin{gathered}
\mathrm{ECBU}=\mathrm{B} \text {-uptake } / c_{\mathrm{w}} m_{\mathrm{w}}\left(\Delta T_{\mathrm{s}^{\prime}}+\sum_{n=1}^{N} \Delta T_{m}\right), \\
N=F\left[K\left(\Delta T_{\mathrm{s}^{\prime}}\right)\left(\frac{\Delta T_{\mathrm{s}^{\prime}}}{\Delta T_{\mathrm{s}^{\prime}}-\Delta T_{m}}\right)^{K}\right] t
\end{gathered}
$$

where $c_{\mathrm{w}}$ is the specific heat capacity of water $(4.2 \mathrm{~kJ} / \mathrm{kg}$ ${ }^{\circ} \mathrm{C}$; Wanner et al. 2005). $m_{\mathrm{w}}$ is the mass of water $(\mathrm{kg})$ and set as $1 \mathrm{~kg} . \Delta T_{s^{\prime}}$ is the temperature change from the reaction temperature $T_{\mathrm{s}}$ to room temperature $T_{\mathrm{a}}\left({ }^{\circ} \mathrm{C}\right) . \Delta T_{m}$ is the temperature changes $\left({ }^{\circ} \mathrm{C}\right)$ and set as $0.5{ }^{\circ} \mathrm{C}$; this meant that the thermoreactor would start automatically when the temperature has a decrease of $0.5{ }^{\circ} \mathrm{C}$ from $T_{\mathrm{s}}$. Furthermore, $N$ is the number of heating times during $t$ ( $\mathrm{min}$ ) of reaction time in the temperature-holding period. $K$ is the rate constant of temperature decline curve by applying first-order exponential decay model $\left(\mathrm{min}^{-1}\right.$; Blundell and Blundell 2006). It was estimated as $0.1 \mathrm{~min}^{-1}$ by Online Resource 1_Eq. S8. $F$ is the modified constant $\left(1 /{ }^{\circ} \mathrm{C}\right)$ and is given as $2\left(1 /{ }^{\circ} \mathrm{C}\right)$ by Online Resource 1_Eq. S9. $t$ is the reaction time ( $\mathrm{min})$.

In Table 2, the ECBU in different reaction conditions was estimated by Eq. 8, and detailed information was summarized in Online Resource 1_Table S3. Because more 
appropriate reaction temperature and time were used, two $\mathrm{Ca}(\mathrm{OH})_{2}$ additions (CAH and SM-CAC) in this study performed well in the energy efficiencies. In addition, the value of ECBU by SM-CAC addition was quite higher than that of by $\mathrm{CAH}$ addition. However, their boron recovery efficiencies were comparatively lower. In contrast, residual boron concentrations had significant decreases when reaction times were longer. But even though the reactions were at low reaction temperatures, the extension of reaction time may raise the whole amount of energy consumption. It is due to higher demand of energy during temperature-holding period (Online Resource 1_Table S3). Additionally, the reaction by more $\mathrm{Ca}(\mathrm{OH})_{2}$ dosage $(50 \mathrm{~g} / \mathrm{L})$ can reach the highest boron efficiency; however, it also led to much lower boron uptake at the same time (Jamis et al. 2002). This meant that the dosage of $\mathrm{Ca}(\mathrm{OH})_{2}$ and energy input are the functions of the recovery efficiency. Thus, the simultaneous consideration of the two factors was strongly recommended.

Boron recovery and reuse from polarizer manufacturing wastewater

In order to investigate the feasibility of boron recovery from a real high-level boron containing wastewater by using sub-micron $\mathrm{Ca}(\mathrm{OH})_{2}$ particles, the polarizer manufacturing wastewater was treated with the optimum condition $\left(10 \mathrm{~g} / \mathrm{L}\right.$ of SM-CAC and SM-CAN, $95^{\circ} \mathrm{C}$ and $1 \mathrm{~h}$ of reaction time). The result showed that residual boron concentrations by the two types of sub-micron $\mathrm{Ca}(\mathrm{OH})_{2}$ additions were similar $(\sim 380 \mathrm{mg} / \mathrm{L}$; Fig. $6 \mathrm{a})$. The concentrations of recovered boron by adding SM-CAC $(50.1 \%)$ and SM-CAN (53.5\%) were almost half of the initial boron concentration. The concentrations of iodide and potassium ions dissolved from the precipitates were quite lower as compared to the residual concentrations of these two ions in solutions (Table 3), and it is more beneficial for boron recovery. Moreover, because of the high boron concentration from the polarizer manufacturing wastewater, it was quite difficult for current treatment technologies to achieve the strict discharge standard $(<1 \mathrm{mg} / \mathrm{L})$ using only one step. In Table 4 , several methods are considered. Among them, chemical precipitation is a potential method for the level of boron in this study $(380 \mathrm{mg} / \mathrm{L})$ because of its higher capacity of boron concentration of influent $(400-1,000 \mathrm{mg} / \mathrm{L})$ and low residual boron concentrations of 5 and $0.5 \mathrm{mg} / \mathrm{L}$ by addition with $\mathrm{Ca}(\mathrm{OH})_{2} / \mathrm{H}_{3} \mathrm{PO}_{4}$ weight ratios of $4: 3$ and 8:3, respectively (Tsai and Lo 2011). Although the higher dose leaded to a rather low residual boron concentration, higher sludge production may hinder the applicability of this method. Therefore, chemical precipitation method with the moderate amount of dose $(\mathrm{Ca} / \mathrm{P}=4: 3)$ was suggested as the second step. Then, two high removal efficiency methods for low-level boron, ion exchange, and reverse osmosis can be considered as the third step in order to achieve the regulation.

To further confirm the components of the recovered precipitates, the precipitates were identified by XRD analysis. The finding shows that stronger diffraction peaks of $\mathrm{Ca}(\mathrm{OH})_{2}$ and $\mathrm{Ca}_{2} \mathrm{~B}_{2} \mathrm{O}_{5} \cdot \mathrm{H}_{2} \mathrm{O}$, and weak peaks of $\mathrm{KI}$ (Fig. 6b). It indicates that the recovered precipitates mainly consisted of $\mathrm{Ca}(\mathrm{OH})_{2}$ and $\mathrm{Ca}_{2} \mathrm{~B}_{2} \mathrm{O}_{5} \cdot \mathrm{H}_{2} \mathrm{O}$, and the simple chemical compositions would be helpful for boron recovery. Additionally, from an economic point of view, it might be highly beneficial in boron recovery if the recovered precipitates have a high enough proportion of boron content. The percentages of boron content in the precipitates obtained from SM-CAC and SM-CAN additions were estimated by Eq. 5, and they were compared with the percentages of natural boron minerals. Both the percentages of boron content in the precipitates made by SM-CAC and SM-CAN were 7.0 and $7.1 \%$, respectively. Their percentages were a little close to the boron content in borax $\left(\mathrm{Na}_{2} \mathrm{~B}_{4} \mathrm{O}_{7} \cdot 10 \mathrm{H}_{2} \mathrm{O} ; 11.3 \%\right)$, a kind of boron minerals of commercial importance (Önal and Burat 2008).

\section{Conclusion}

In the present study, effective sub-micron $\mathrm{Ca}(\mathrm{OH})_{2}$ particles for the improvement of boron recovery from concentrated wastewater were developed. The following conclusions can be drawn from this study. The two types of sub-micron $\mathrm{Ca}(\mathrm{OH})_{2}$ particles, SM-CAC and SM-CAN, provided better boron recovery efficiencies than $\mathrm{Ca}(\mathrm{OH})_{2}$ without modifying at the moderate temperature $\left(95^{\circ} \mathrm{C}\right)$. Under high reaction temperature, faster rates of mass transport and surface reaction would enhance the mineralization rate of $\mathrm{Ca}-\mathrm{B}$ particle and boron recovery efficiency. On the other hand, various particle sizes may play a primary role in the conditions with low reaction temperature. For the real wastewater study, the formation of $\mathrm{Ca}_{2} \mathrm{~B}_{2} \mathrm{O}_{5} \cdot \mathrm{H}_{2} \mathrm{O}$ may be inhibited by the lower $\mathrm{pH}$ values in the polarizer manufacturing wastewater. However, the boron contents in the recovered precipitates showed the close percentages to be worth recovering. In addition, in order to recover and removal boron from high-level boron wastewater, a combined treatment process was proposed. First, two-step chemical precipitation is used to recover and removal of high concentration of boron from waste- 
water. Sub-micron $\mathrm{Ca}(\mathrm{OH})_{2}$ and low ECBU conditions are used to recover boron. Then, the residual boron in the solutions can remove by secondary chemical precipitation with moderate $\mathrm{Ca} / \mathrm{P}$ dosage. In the final step, ion exchange and reverse osmosis methods might be more appropriate to reduce the boron concentration in wastewater to meet the strict discharge standard.

Acknowledgments The authors are thankful to the National Science Council of the Republic of China (Project No.: NSC 98-2221-E040-MY3) for financial support and to Dr. Vinay Kumar Tyagi for very useful comments.

\section{References}

Anderson JL, Eyring EM, Whittaker MP (1963) Temperature jump rate studies of polyborate in aqueous boric acid. J Phys Chem 68:1128-1132

Angulo MA, Crangle Jr RD (2010) Metals and minerals: U.S. geological survey minerals yearbook, vol 1. U.S. Geological Survey, Virginia

Blundell SJ, Blundell KM (2006) Concepts in thermal physics. Oxford University Press, New York

Böke H, Akkurt S, Özdemir S, Göktürk EH, Caner Saltik EN (2004) Quantification of $\mathrm{CaCO}_{3}-\mathrm{CaSO}_{3} \cdot 0.5 \mathrm{H}_{2} \mathrm{O}$ $\mathrm{CaSO}_{4} \cdot 2 \mathrm{H}_{2} \mathrm{O}$ mixtures by FTIR analysis and its ANN model. Mater Lett 58:723-726

Chong MF, Lee KP, Chieng HJ, Syazwani Binti Ramli II (2009) Removal of boron from ceramic industry wastewater by adsorption-flocculation mechanism using palm oil mill boiler (POMB) bottom ash and polymer. Water Res 43:3326-3334

del Mar de la Fuente García-Soto M, Camacho EM (2006) Boron removal by means of adsorption with magnesium oxide. Sep Sci Technol 48:36-44

Dionisiou N, Matsi T, Misopolinos ND (2006) Use of magnesia for boron removal from irrigation water. $\mathrm{J}$ Environ Qual 35:2222-2228

Ezechi EH, Isa MH, Kutty SR, Spari BN (2011) Boron recovery, application and economic significance: a review. National Postgraduate Conference, pp 1-6

Fogler HS (2004) Elements of chemical reaction engineering, 3rd edn. Prentice-Hall, New Jersey

Girgin S, Kazanci N, Dügel M (2010) Relationship between aquatic insects and heavy metals in an urban stream using multivariate techniques. Int J Environ Sci Tech 7(4):653-664

Hirao T, Kotaka M, Kakihana H (1979) Raman spectra of polybroate ions in aqueous solution. J Nucl Chem 41:1217-1220

Irawan C, Kuo YL, Liu JC (2011) Treatment of boron-containing optoelectronic wastewater by precipitation process. Desalination 280:146-151

Itakura T, Sasai R, Itoh H (2005) Precipitation recovery of boron from wastewater by hydrothermal mineralization. Water Res 39:2543-2548

Jamis P, Muhr H, Plasari E (2002) Boron removal from waste solutions using a multiphase co-precipitation process. Chem Eng Trans 1:975-981

Jun L, Shuping X, Shiyang G (1995) FT-IR and Raman spectroscopic study of hydrated borates. Spectrochim Acta A Mol Biomol Spectrosc 51:519-532

Kabay N, Sarp S, Yuksel M, Arar O, Bryjak M (2007) Removal of boron from seawater by selective ion exchange resins. React Func Polym 67:1643-1650
Kabay N, Güler E, Bryjak M (2010) Boron in seawater and methods for its separation-a review. Desalination 261:212-217

López FJ, Giménez E, Hernández F (1993) Analytical study on the determination of boron in environmental water samples. Fresenius' J Anal Chem 346:984-987

Mattigod SV, Frampton JA, Lim CH (1985) Effect of ion-pair formation on boron adsorption by kaolinite. Clays Clay Miner 33:433-437

Mohapatra D, Chaidhury GR, Park KH (2008) Recovery of boron from wastewater using 2, 2, 4-trimethyl-1,3-pentanediol in carbon tetrachloride. Indian J Chem Technol 15:83-487

Mullin JW (2001) Crystallization, 4th edn. Butterworth-Heinemann, Oxford

Önal G, Burat F (2008) Boron mining and processing in Turkey. Gospod Surowcami Min 24:51-60

Oo MH, Ong SL (2010) Implication of zeta potential at different salinities on boron removal by RO membranes. J Membr Sci 352:1-6

Özdemir M, Kıpçak İ (2010) Recovery of boron from borax sludge of boron industry. Miner Eng 23:685-690

Öztürk N, Kavak D (2005) Adsorption of boron from aqueous solutions using fly ash: batch and column studies. J Hazard Mater 127:81-88

Parks GA (1967) Aqueous surface chemistry of oxides and complex oxide minerals. In: Stumm W (ed) Equilibrium concepts in natural water systems. American Chemical Society, Washington, pp 121-160

Parks JL, Edwards M (2005) Boron in the environment. Crit Rev Environ Sci Technol 35:81-114

Polat H, Vengosh A, Pankratov I, Polat M (2004) A new methodology for removal of boron from water by coal and fly ash. Desalination 164:173-188

Redondo J, Busch M, De Witte JP (2003) Boron removal from seawater using FILMTECTM high rejection SWRO membranes. Desalination 156:229-238

Robinson MG, Chen J, Sharp GD (2005) Polarization engineering for LCD projection. Wiley, England

Roskill Information Service Ltd (2006) The economics of boron, 11th edn. Roskill Information Service Ltd, London

Schaezler DJ (1978) Precipitation of calcium aluminates and sulfoaluminates from water. Water Pollut Control Fed 50:1821-1826

Schubert DM (2003) Borates in industrial use. Struct Bond 105: $1-40$

Simonnot M-O, Castel C, Nicola M, Rosin C, Sardin M, Jauffret H (2000) Boron removal from drinking water with a boron selective resin: is the treatment really selective. Water Res 34:109-116

Su C, Suarez DL (1995) Coordination of adsorbed boron: a FTIR spectroscopic study. Environ Sci Technol 29:302-311

Sugimoto T (2011) Monodispersed particles. Elsevier Science, Amsterdam

Taniguchi M, Fusaoka Y, Nishikawa T, Kurihara M (2004) Boron removal in RO seawater desalination. Desalination 167:419-426

Tsai HC, Lo SL (2011) Boron removal and recovery from concentrated wastewater using a microwave hydrothermal method. J Hazard Mater 186:1431-1437

Tsai HC, Lo SL, Kuo J (2011) Using pretreated waste oyster and clam shells and microwave hydrothermal treatment to recover boron from concentrated wastewater. Bioresour Technol 102:7802-7806

Wanner O, Panagiotidis V, Clavadetscher P, Siegrist H (2005) Effect of heat recovery from raw wastewater on nitrification and nitrogen removal in activated sludge plants. Water Res 39:4725-4734

World Health Organization (1998) Environmental health criteria 204 for boron. World Health Organization, Geneva 
Yan C, Yi W, Ma P, Deng X, Li F (2008) Removal of boron from refined brine by using selective ion exchange resins. J Hazard Mater 154:564-571
Yoshikawa E, Sasaki A, Endo M (2012) Removal of boron from wastewater by the hydroxyapatite formation reaction using acceleration effect of ammonia. J Hazard Mater 237-238:277-282 